\title{
Pemberdayaan Teknik Bercerita Berbasis Budaya Bali Dalam Pembelajaran Keterampilan Menulis Karangan Pribadi Siswa Kelas V SD Mutiara Singaraja
}

\author{
I Ketut Dibia1, *, I Putu Mas Dewantara², I Wayan Widiana ${ }^{3}$ \\ 1 Jurusan Pendidikan Guru Sekolah Dasar, Universitas Pendidikan Ganesha, Indonesia \\ 2 Jurusan Pendidkan Bahasa dan Sastra Indonesia, Universitas Pendidikan Ganesha, Indonesia \\ ${ }_{3}^{3}$ Jurusan Pendidikan Guru Sekolah Dasar, Universitas Pendidikan Ganesha, Indonesia
}

\begin{abstract}
The aim of this research were to find out (1) the steps of story telling technique based Balinese culture in teaching writing pesonal story skill of fifth-grade students in SD Mutiara Singaraja, (2) students' learning outcome of fifth-grade students in SD Mutiara Singaraja by empowering of story telling technique based Balinese culture in teaching writing pesonal story skill. This research was descriptive qualitative. The subject of this research were teacher and fifth-grade students' of SD Mutiara Singaraja. The object of this study were the steps of story telling technique based Balinese culture in teaching writing pesonal story skill of fifth-grade students in SD Mutiara Singaraja, students' learning outcome of five-grade students in SD Mutiara Singaraja by empowering of story telling technique based Balinese culture in teaching writing pesonal story skill. The data were collected by observing and testing. The result of the analysis showed that (1) the teacher did the learning activity effectively by story telling technique based Balinese culture, in preliminary, main activity , and closure, those the learning objectives could be achieved. (2) The students' learning outcome of five-grade students in SD Mutiara Singaraja by empowering of story telling technique based Balinese culture in teaching writing pesonal story skill were in spendid category, that was about 93.7. Therefore, it could be concluded that the story telling technique based Balinese culture was effective to be applaid in teaching writing pesonal story skill, those the students could show the optimal learning out come.
\end{abstract}

\section{Keywords:}

Story Telling Technique,

Writing Personal Story,

Balinese Culture

\section{Pendahuluan}

Pembelajaran Bahasa Indonesia berdasarkan diarahkan kepada pencapaian keterampilan berbahasa yang mencakup empat aspek, yaitu menyimak, berbicara, membaca, dan menulis. Keraf (2001) menyatakan keempat keterampilan berbahasa tersebut saling berhubungan. Seperti keterampilan berbahasa yang lain, menulis sangat penting untuk diperhatikan dalam pembelajaran bahasa di sekolah, khususnya pembelajaran Bahasa Indonesia. Keterampilan menulis merupakan sarana yang penting bagi siswa. Dalam hal ini, dengan keterampilan menulis, siswa mampu mengembangkan keterampilan bercerita, membantu penalaran yang logis atau kritis, mengungkapkan fakta-fakta, perasaan, sikap dan isi pikiran secara jelas dan efektif kepada pembaca.

Menurut Tarigan (2008:2), menulis adalah menurunkan atau melukiskan lambang-lambang grafik yang menggambarkan suatu bahasa yang dapat dipahami oleh seseorang sehingga orang lain dapat membaca dan memahami lambang-lambang grafik itu. Aktivitas menulis merupakan suatu bentuk manifestasi kompetensi berbahasa paling akhir yang dikuasai dalam pembelajaran bahasa setelah menyimak, berbicara, dan membaca. Dibadingkan dengan ketiga kompetensi berbahasa yang lain, keterampilan menulis secara umum boleh dikatakan lebih sulit dikuasai bahkan oleh penutur asli bahasa yang bersangkutan (Nurgiyantoro, 2010:422). Hal ini disebabkan oleh keterampilan menulis menghendaki penguasaan berbagai unsur kebahasaan dan unsur di luar bahasa itu sendiri sehingga menghasilkan karangan yang runtut, padu, dan mudah dipahami oleh pembaca. Selain itu, menulis menghendaki orang untuk menguasai lambang atau simbol-simbol visual dan aturan tata tulis yang

\footnotetext{
* Corresponding author.

E-mail Addresses: iketut.dibia@undiksha.ac.id (I Ketut Dibia), mas.dewantara@undiksha.ac.id (I Putu Mas Dewantara),

wayanwidiana85@undiksha.ac.id (I Wayan Widiana)
} 
menyangkut ejaan. Kelancaran komunikasi dalam suatu karangan sama sekali tergantung pada bahasa yang dilambang-visualkan.

Berbagi pandangan di atas mengisyaratkan bahwa menulis merupakan bagian yang tak terpisahkan dari keseluruhan kegiatan belajar siswa. Oleh sebab itu, sebagaimana jenis keterampilan yang lain, keterampilan menulis perlu mendapatkan perhatian guru maupun siswa. Dalam hal ini, guru sebagai pengajar seharusnya memiliki kemampuan tulis-menulis yang memadai untuk diajarkan kepada siswanya. Terkait dengan hal itu, tujuan yang diharapkan dalam pembelajaran menulis adalah agar siswa mampu mengungkapkan gagasan, pendapat, dan pengetahuan secara tertulis serta memiliki kegemaran menulis. Dengan keterampilan menulis yang dimiliki, siswa dapat mengembangkan kreativitas dan dapat mempergunakan bahasa sebagai sarana menyalurkan kreativitasnya dalam kehidupan sehari-hari.

Pembelajaran menulis pada siswa sekolah dasar (SD) salah satunya menuntut siswa menguasai bentuk karangan yang berdasarkan pada pengalaman pribadi. Karangan adalah suatu bentuk sistem komunikasi lambang visual (Nurgiantoro, 2010: 423). Trianto (2009: 45) menyatakan "Hal yang paling mendasar yang dituntut dalam proses pembelajaran menulis karangan adalah daya kreativitas siswa." Keaktifan daya kreativitas siswa dalam proses pembelajaran menulis karangan sangat dibutuhkan agar siswa mampu menuangkan ide ke dalam sebuah karangan. Pembelajaran menulis karangan berdasarkan pengalaman merupakan salah satu pembelajaran yang banyak menuntut keaktifan pikiran siswa untuk menciptakan tulisan yang maksimal. Oleh karena itu, untuk menciptakan keaktifan siswa dalam menulis karangan, diperlukanlah suatu teknik yang tepat dan inovatif.

Hasil observasi yang dilakukan di kelas V SD Mutiara Singaraja menunjukkan bahwa sebagian siswa belum dapat menulis karangan dengan baik. Dalam hal ini, siswa kurang memperhatikan penggunaan tanda baca, kaidah-kaidah penulisan, penggunaan bahasa atau penggunaan kata dan penyusunan kalimat dengan struktur yang benar, sampai dengan penyusunan atau pengembangan paragraf. Dari hasil pengamatan peneliti, masalah yang dihadapi oleh siswa juga disebabkan oleh proses pembelajaran yang diterapkan oleh guru. Dalam hal ini, guru masih mengajar secara konvensional, yaitu menerapkan metode ceramah yang disertai contoh seperlunya. Itu menunjukkan bahwa kemampuan guru dalam menggunakan teknik, strategi, metode, dan media masih kurang. Kegiatan pembelajaran yang dilakukan sangat monoton dan tidak menarik sehingga siswa menjadi bosan. Saat guru menjelaskan, banyak siswa terkesan tidak serius walaupun pada umumnya mereka tampak tenang saat pembelajaran berlangsung. Setelah menjelaskan, guru memberikan tugas mengarang. Karangan yang telah dikoreksi, dibagikan lagi oleh guru kepada siswa. Sebagai upaya perbaikan, guru melakukan perbaikan terhadap beberapa kesalahan siswa. Dalam hal ini, guru adakalanya melibatkan siswa dalam perbaikan tersebut, tetapi hanya melibatkan siswa secara klasikal, bahkan hanya melibatkan beberapa siswa yang aktif.

Dari permasalahan tersebut, pemilihan teknik pembelajaran yang tepat perlu diupayakan untuk memudahkan proses terbentuknya pengetahuan pada siswa. Siswa sebagai sasaran dalam pembelajaran harus dibentuk menjadi siswa yang aktif, kreatif, dan inovatif. Teknik pembelajaran yang baik dan relevan menurut beberapa ahli adalah teknik pembelajaran yang mampu mengantarkan siswa untuk mencapai tujuan pembelajaran. Pemilihan, perencanaan, dan penerapan teknik pembelajaran yang sesuai akan membantu jalannya proses pembelajaran Bahasa Indonesia. Dalam memilih dan menentukan teknik pembelajaran, diperlukan suatu pertimbangan dan wawasan yang baik. Teknik pembelajaran dapat digunakan sebagai sudut pandang atau titik tolak untuk memahami seluruh persoalan dalam proses pembelajaran. Sudut pandang menggambarkan cara berpikir pengajar dalam menjalankan profesinya. Teknik pembelajaran yang diterapkan oleh guru merupakan suatu proses usaha untuk memperoleh suatu perubahan yang baru dalam diri siswa sebagai hasil pengalamannya sendiri dalam interaksi dengan lingkungannya.

Penerapan suatu teknik pembelajaran inovatif perlu dilakukan dalam pembelajaran Bahasa Indonesia. Hal ini perlu dilakukan untuk memaksimalkan keaktifan dan peran serta siswa dalam pembelajaran. Salah satu teknik pembelajaran yang layak diterapkan dalam pembelajaran menulis karangan berdasarkan pengalaman pribadi adalah teknik bercerita. Bercerita adalah menuturkan sesuatu yang mengisahkan tentang perbuatan atau sesuatu kejadian dan disampaikan secara lisan dengan tujuan membagikan pengalaman dan pengetahuan kepada orang lain (Bachri, 2005:10). Bercerita merupakan salah satu keterampilan berbahasa yang bersifat produktif yang berarti menghasilkan ide, gagasan, dan buah pikiran (Yeti Mulyati, 2009: 64).

Teknik bercerita adalah cara penyampaian atau penyajian materi pembelajaran secara lisan dalam bentuk cerita dari guru kepada anak didik. Dalam pelaksanaan kegiatan pembelajaran di SD, teknik bercerita dilaksanakan dalam upaya memperkenalkan, memberikan keterangan, atau penjelasan tentang hal baru dalam rangka menyampaikan pembelajaran yang dapat mengembangkan berbagai kompetensi dasar. Oleh karena itu, materi yang disampaikan berbentuk cerita yang awal dan akhirnya berhubungan erat dalam kesatuan yang utuh, maka cerita tersebut harus dipersiapkan terlebih dahulu. Biasanya 
kegiatan bercerita dilaksanakan pada kegiatan penutup sehingga kalau anak pulang, anak menjadi tenang dan senang setelah mengikuti pembelajaran. Namun demikian, pada praktiknya tidak selalu pada saat kegiatan penutup. Bercerita dapat dilakukan pada saat kegiatan pembukaan, kegiatan inti, maupun pada waktu-waktu senggang di sekolah. Misalnya, pada saat waktu istirahat, karena mendengarkan cerita adalah sesuatu yang mengasyikkan bagi siswa SD.

Teknik bercerita ini sangat penting diterapkan dalam pembelajaran menulis di sekolah dasar. Dalam hal ini, teknik bercerita dapat dilakukan dengan menggunakan cerita berbasis budaya Bali (kearifan lokal). Pada fase ini sangatlah strategis apabila kegiatan menulis karangan dan enkulturasi pada siswa SD ini dilakukan secara fokus dan intensif. Melalui teknik ini, secara langsung dapat ditanamkan nilai-nilai kearifan lokal sebagai nurturant effect. Integrasi budaya dan potensi lokal itu meniscayakan fungsi yang strategis bagi pembentukan karakter dan identitas. Di samping itu, dengan pemberdayaan teknik tersebut, siswa akan lebih mudah menulis karangan sesuai dengan pengalamannya masing-masing.

Ada beberapa alasan mengapa pembelajaran menulis karangan perlu dikaitkan dengan cerita berbasis budaya Bali. Subiantoro (2012:100) mengatakan bahwa cerita yang bermuatan merupakan media membangun karakter pada anak. Hasil penelitian Sintia Wati, dkk. (2016) menyangkut penerapan metode bercerita berbasis kearifan lokal menunjukkan keberhasilan dalam mengembangkan empati anak kelompok B1. Penerapan metode bercerita berbasis kearifan lokal dalam meningkatkan moral anak juga menunjukkan keberhasilan pada penelitian yang dilakukan Eka Jayanti, dkk. (2016). Beranjak dari temuan penelitian tersebut, menurut peneliti, pembelajaran dengan teknik bercerita dengan menggunakan cerita berbasis budaya Bali akan mampu menjadikan pembelajaran lebih bermakna, yakni bermanfaat karena dapat membantu siswa dalam kehidupan sehari-hari. Apa yang diperoleh oleh siswa di sekolah dengan apa yang dialaminya dalam kehidupan sehari-hari tidak stagnant. Di samping itu, pembelajaran menjadi lebih dekat dengan siswa, baik secara fisik maupun psikis. Dekat secara fisik, maksudnya terdapat dalam lingkungan tempat tinggal dan sekolah siswa. Dengan kata lain, lingkungan siswa dimanfaatkan untuk memperoleh pengalaman belajar. Dekat secara psikis maksudnya bahan kajian dalam pembelajaran mudah dipahami oleh kemampuan berpikir dan mencerna informasi sesuai dengan usia siswa.

Penelitian kearifan lokal yang dilakukan selama ini digunakan untuk meningkatkan empati dan juga moral. Belum terdapat penelitian yang menggunakan cerita berbasis kearifan lokal dalam pembelajaran menulis karangan pribadi. Karena itu, penelitian ini penting dilakukan untuk melihat penerapan bercerita berbasis kearifan lokal dalam pembelajaran menulis. Penelitian lain yang mengangkat keterampilan menulis pernah dilakukan oleh Siti Mundziroh (2013) yang meneliti peningkatan kemampuan menulis cerita dengan metode picture and picture pada siswa kelas V SD Muhammadiyah 11 Mangkuyudan Surakarta. Rumbiak (2016) juga pernah melakukan penelitian yang menggunakan media gambar dalam menulis cerita. Penelitian Khotimah, dkk. (2016) menunjukkan bahwa Model Cooperative Script dengan Media Flashcard Berbasis Kearifan Lokal berhasil meningkatkan kemampuan siswa dalam menulis karangan pada siswa kelas IV.

Melihat penelitian-penelitian terdahulu, belum ada penelitian yang sama dengan penelitian ini. Kebaharuan penelitian ini terletak pada upaya dalam mendeskripsikan penggunaan teknik bercerita berbasis budaya Bali dalam pembelajaran menulis karangan pribadi. Karena itu, tujuan penelitian ini adalah (1) untuk mengetahui langkah-langkah teknik bercerita berbasis budaya Bali dalam pembelajaran keterampilan menulis karangan pribadi dan (2) untuk mengetahui hasil belajar siswa kelas V SD Mutiara Singaraja dengan memberdayakan teknik bercerita berbasis budaya Bali dalam pembelajaran keterampilan menulis karangan pribadi.

\section{Metode}

Penelitian ini menggunakan rancangan deskriptif kualitatif. Penelitian deskriptif dimaksudkan untuk memperoleh gambaran yang jelas, objektif, sistematis, dan cermat mengenai fakta-fakta yang diperoleh. Metode ini menekankan pada ketajaman analisis secara objektif sehingga diperoleh ketepatan dalam interpretasi. Subjek penelitian ini adalah guru dan siswa kelas V SD Mutiara Singaraja. Peneliti dalam menentukan subjek penelitian ini didasarkan atas pertimbangan bahwa subjek di kelas V SD Mutiara Singaraja memiliki kecendrungan hasil belajar menulis karangan pribadi yang kurang optimal. Objek penelitian ini adalah langkah-langkah pembelajaran dengan memberdayakan teknik bercerita melalui menyimak cerita berbasis budaya Bali dalam pembelajaran keterampilan menulis karangan pribadi siswa kelas V SD Mutiara Singaraja dan hasil belajar siswa kelas V SD Mutiara Singaraja dengan memberdayakan teknik bercerita melalui menyimak cerita berbasis budaya Bali dalam pembelajaran keterampilan menulis karangan pribadi.

Metode pengumpulan data yang digunakan dalam penelitian ini adalah metode observasi dan tes. Alasan peneliti menggunakan metode tersebut, karena penelitian ini merupakan penelitian deskriptif 
yang hanya menggambarkan dan menginterpretasikan suatu objek. Metode analisis data yang digunakan terdiri atas tiga langkah, yaitu reduksi data, penyajian data, dan penarikan simpulan. Pada tahap reduksi data, kegiatan yang dilakukan adalah memilih hal-hal pokok yang sesuai dengan fokus permasalahan penelitian dan data yang kurang penting disisihkan. Data yang kurang penting dipertimbangkan lagi bila diperlukan. Dalam reduksi data ini, peneliti terlebih dahulu mengumpulkan data melalui observasi dan tes.

Dalam penelitian ini, reduksi data dilakukan melalui kegiatan yang berupa pengidentifikasian dan pengklasifikasian. Data berupa pemberdayaan teknik bercerita melalui menyimak cerita berbasis budaya Bali yang telah ditranskripsikan dari hasil observasi dan tes, kemudian diidentifikasi dan diberi kode untuk memudahkan peneliti dalam menganalisis data. Dengan cara itu, akan diperoleh data yang menunjukan pemberdayaan teknik bercerita melalui menyimak cerita berbasis budaya Bali dalam pembelajaran keterampilan menulis karangan pribadi pada siswa kelas V SD Mutiara Singaraja.

Setelah diidentifikasi, selanjutnya data mengenai pemberdayaan teknik bercerita melalui menyimak cerita berbasis budaya Bali ditata dan diklasifikasi. Dalam hal ini, data yang sudah diidentifikasi dan direduksi, ditata dan diklasifikasikan sesuai dengan masalah yang dikaji, yaitu langkah-langkah pembelajaran dengan memberdayakan teknik bercerita melalui menyimak cerita berbasis budaya Bali dalam pembelajaran keterampilan menulis karangan pribadi siswa kelas V SD Mutiara Singaraja dan hasil belajar siswa kelas V SD Mutiara Singaraja dengan memberdayakan teknik bercerita melalui menyimak cerita berbasis budaya Bali dalam pembelajaran keterampilan menulis karangan pribadi. Setelah data digolongkan sesuai dengan rumusan masalah, selanjutnya data tersebut akan disajikan untuk memperoleh jawaban yang tepat dan sesuai dengan rumusan masalah sehingga data tersebut dapat menjawab permasalahan yang diangkat dalam penelitian ini. Data-data yang telah direduksi akan disajikan uraian data yang nantinya akan digambarkan secara rinci dan jelas. Dalam penyajian data ini, data yang didapat akan dihubungkan dengan teori-teori yang relevan yang nantinya akan dapat menjawab permasalahan yang ingin dipecahkan. Pada tahap ini, data mengenai pemberdayaan teknik bercerita melalui menyimak cerita berbasis budaya Bali akan dikumpulkan serta dipaparkan dengan jenis wacana deskripsi yang sesuai dengan rancangan penelitian.

Untuk mengetahui keakuratan penelitian, penyimpulan sangat penting dilakukan. Penyimpulan yang dilakukan harus dapat menjawab semua masalah yang diangkat dalam penelitian tersebut sehingga hasil akhirnya nanti akan diperoleh informasi mengenai pemberdayaan teknik bercerita melalui menyimak cerita berbasis budaya Bali dalam pembelajaran keterampilan menulis karangan pribadi pada siswa kelas V SD Mutiara Singaraja.

\section{Hasil dan Pembahasan}

Hasil penelitian menunjukkan bahwa kemampuan menulis karangan pribadi siswa berada dalam kualifikasi baik sekali. Ada beberapa hal yang dianggap penting sehubungan dengan pemberdayaan teknik bercerita melalui menyimak cerita berbasis budaya Bali dalam pembelajaran keterampilan menulis karangan pribadi. Temuan-temuan yang dimaksud adalah sebagai berikut. (1) Pemberdayaan teknik bercerita melalui menyimak cerita berbasis budaya Bali memudahkan siswa untuk menulis karangan pribadi; (2) Pemberdayaan teknik bercerita melalui menyimak cerita berbasis budaya Bali membuat hasil belajar siswa berada dalam kategori baik sekali; (3) Pemberian bimbingan dan penghargaan oleh guru dapat mendorong siswa untuk menjadi lebih baik.

Berdasarkan hasil penelitian yang telah dipaparkan di atas, dapat diidentifikasi 2 temuan yang bermakna. Kedua temuan tersebut akan dibahas satu demi satu berikut ini.

1. Langkah-langkah teknik bercerita berbasis budaya Bali dalam pembelajaran keterampilan menulis karangan pribadi siswa kelas V SD Mutiara Singaraja.

Berbicara mengenai teknik pembelajaran, tentunya tidak terlepas dari langkah-langkah yang digunakan oleh guru dalam menerapkan teknik pembelajaran tersebut. Sesuai dengan hasil penelitian terhadap guru yang mengajar di kelas V SD Mutiara Singaraja, guru telah memberdayakan teknik bercerita sesuai dengan rencana pelaksanaan pembelajaran. Penerapan teknik pembelajaran tersebut sudah diintegrasikan dalam tahapan pembelajaran, baik pada tahap awal, inti, maupun penutup. Hai itu sudah dilakukan dengan baik oleh guru walaupun ada yang tidak sesuai dengan yang telah direncanakan sebelumnya. Akan tetapi, semua prosedur dalam mengajar telah dilaksanakan dengan baik dan dengan memberdayakan teknik bercerita dalam pembelajaran menulis, siswa dapat menghasil kan tulisan dengan kategori baik sekali. Di samping itu, dengan memberdayakan teknik bercerita dalam pembelajaran menulis, siswa menjadi antusias mengikuti pelajaran dan mampu menghasilkan tulisan yang bermanfaat bagi kehidupan mereka kelak. 
Berdasarkan hasil penelitian, guru memberdayakan teknik bercerita berbasis budaya Bali. Dalam hal ini, bercerita merupakan proses menuturkan sesuatu yang mengisahkan tentang perbuatan atau sesuatu kejadian dan disampaikan secara lisan dengan tujuan membagikan pengalaman dan pengetahuan kepada orang lain (Bachri, 2005:10). Dengan kata lain, bercerita adalah menuturkan sesuatu yang mengisahkan tentang perbuatan atau suatu kejadian secara lisan sebagai upaya mengembangkan potensi kemampuan berbahasa. Dalam pelaksanaannya di dalam kelas, teknik bercerita dilaksanakan sebagai upaya memperkenalkan, memberikan keterangan, atau penjelasan tentang hal baru dalam rangka menyampaikan pembelajaran yang dapat mengembangkan berbagai kompetensi dasar. Oleh karena itu, materi yang disampaikan berbentuk cerita yang awal dan akhirnya berhubungan erat dalam kesatuan yang utuh.

Proses pembelajaran dengan teknik bercerita berbasis budaya Bali secara implisit dapat mendorong siswa untuk mengonstruksikan pengetahuan di benak mereka sendiri. Hal ini dilakukan melalui kegiatan-kegiatan belajar, seperti memberikan orientasi awal kepada siswa sehingga dapat membina suasana atau iklim pembelajaran yang responsif. Guru berusaha semaksimal mungkin mengondisikan siswa agar siap melaksanakan proses pembelajaran, yaitu dengan cara memberikan beberapa pertanyaan yang berkaitan dengan materi yang akan dipelajari. Hal ini bertujuan untuk menggali pemahaman awal siswa, serta membuat siswa berpikir dalam mempersiapkan dirinya ketika guru memberikan pertanyaan kepada mereka. Cara-cara yang seperti itu merupakan suatu teknik yang baik untuk mengondisikan siswa agar mau mengikuti pelajaran, bahkan kondisi kelas pun akan semakin kondusif.

Melalui teknik bercerita inil guru berupaya untuk memperbaiki hasil belajar menulis karangan pribadi siswa. Apalagi cerita yang disampaikan adalah cerita dari daerah peserta didik sendiri, karena pada fase ini sangatlah strategis apabila kegiatan menulis karangan dan enkulturasi pada siswa SD dilakukan secara fokus dan intensif. Melalui teknik ini, secara langsung dapat ditanamkan nilai-nilai kearifan lokal sebagai nurturant effect. Integrasi budaya dan potensi lokal itu meniscayakan fungsi yang strategis bagi pembentukan karakter dan identitas. Hal ini sejalan dengan hasil penelitian Subiantoro (2012) bahwa pembelajaran yang bermuatan nilai akan membentuk karakter anak. Di samping itu, dengan pemberdayaan teknik tersebut, siswa akan lebih mudah menulis karangan sesuai dengan pengalamannya masing-masing.

Memperkenalkan cerita dalam bentuk mendongeng merupakan budaya bangsa kita. Oleh karena itu, belajar dengan cara seperti ini lebih mudah dirasakan siswa. Bimo (2011) mengatakan bahwa dongeng adalah sarana penanaman karakter yang baik karena siswa senang menerimanya. Meskipun bentuk cerita hanya sebuah dongeng, tetapi dalam dongeng tersebut mengusung pesan berharga. Salah satu contoh di antaranya dalam dongeng dari Bali yang dipilih oleh guru, yaitu berjudul "Ni Timun Mas dan I Lantang Hidung" yang memberikan pelajaran menarik bahwa di dalam hidup ini kita harus saling tolongmenolong. Cerita yang bertuah seperti itu sangat tepat diberikan kepada siswa sehingga siswa memiliki cerminan dalam berperilaku. Dalam dongeng, banyak terkandung budi pekerti yang dapat dipetik nilainya. Budi pekerti dalam dongeng yang mengandung kearifan lokal dapat dilihat dari sisi nilai moral yang ada dalam cerita. Nilai moral tersebut antara lain, moral individu, moral sosial, dan moral religi.

Dengan menyampaikan cerita yang memiliki nilai moral tersebut, secara implisit sudah ditanamkan nilai-nilai karakter ke dalam diri peserta didik. Oleh karena itu, materi yang disampaikan berbentuk cerita berbasis budaya Bali ini sangat tepat diberikan kepada siswa kelas V SD Mutiara Singaraja, karena materinya berbentuk cerita yang awal dan akhirnya berhubungan erat dalam satu kesatuan yang utuh. Ini berarti, bercerita kepada anak memainkan peranan penting bukan saja dalam menumbuhkan minat dan kebiasaan membaca, tetapi juga dalam mengembangkan bahasa dan pikiran anak. Kegiatan bercerita ini sangatlah membantu perkembangan bahasa anak dan dengan bercerita pendengaran anak dapat difungsikan dengan baik, untuk kemampuan berbicara dengan menambah perbendaharaan kosakata, kemampuan mengucapkan kata-kata, melatih merangkai kalimat sesuai dengan tahap perkembangannya. Selanjutnya, anak dapat mengekpresikannya melalui menulis sehingga pada akhirnya anak mampu menulis dengan baik.

Kegiatan pembelajaran dengan teknik bercerita dengan menggunakan cerita berbasis budaya Bali ini mampu menjadikan pembelajaran lebih bermakna, yakni bermanfaat karena dapat membantu siswa dalam kehidupan sehari-hari. Apa yang diperoleh oleh siswa di sekolah dengan apa yang dialaminya dalam kehidupan sehari-hari tidak stagnant. Di samping itu, pembelajaran menjadi lebih dekat dengan siswa, baik secara fisik maupun psikis. Dekat secara fisik, maksudnya terdapat dalam lingkungan tempat tinggal dan sekolah siswa. Dengan kata lain, lingkungan siswa dimanfaatkan untuk memperoleh pengalaman belajar. Dekat secara psikis maksudnya bahan kajian dalam pembelajaran mudah dipahami oleh kemampuan berpikir dan mencerna informasi sesuai dengan usia siswa. 
2. Hasil belajar siswa kelas V SD Mutiara Singaraja dengan memberdayakan teknik bercerita berbasis budaya Bali dalam pembelajaran keterampilan menulis karangan pribadi

Berdasarkan hasil penelitian, skor yang diperoleh siswa kelas V SD Mutiara Singaraja dalam menulis karangan pribadi dengan teknik bercerita melalui menyimak cerita berbasis budaya Bali menunjukkan hasil yang baik sekali. Hal ini ditunjukkan oleh skor rata-rata yang diperoleh siswa, yaitu sebesar 93,7. Sesuai dengan pedoman konversi skala sebelas, rentangan skor 85-94 dinyatakan dalam kategori baik sekali. Jadi, hasil belajar siswa kelas V SD Mutiara Singaraja dalam menulis karangan pribadi dengan teknik bercerita melalui menyimak cerita berbasis budaya Bali berada dalam kategori baik sekali, yaitu sebesar 93,7. Skor tertinggi yang diperoleh siswa dalam menulis karangan pribadi, yaitu sebesar 91 . Tingginya skor yang diperoleh oleh siswa mencerminkan siswa mampu membuat kalimat yang baik dan gagasan yang diungkapkan sangat jelas. Di samping itu, substansi yang dikembangkan sudah relevan dengan permasalahan yang dikemukakan serta menunjukkan hubungan yang kohesif antarkalimat.

Di balik semua itu, ternyata ada dua siswa yang memperoleh skor 70 dalam menulis karangan pribadi. Skor tersebut merupakan skor terendah dari seluruh siswa yang dijadikan subjek dalam penelitian. Rendahnya skor siswa dikarenakan oleh kurangnya pemahaman siswa terhadap unsur konstruksi kalimat yang menyebabkan kalimat yang dibuat tidak mewakilkan gagasan yang ingin disampaikan. Hal lain yang menyebabkan rendahnya kualitas karangan pribadi siswa ialah salah penggunaan bentuk kebahasaan yang berpengaruh terhadap kalimat, urutan dan pengembangan gagasan yang tidak logis, tidak menguasai aturan penulisan, dan tidak menunjukkan hubungan yang kohesif antarkalimat sehingga kualitas karangan pribadi menjadi sangat buruk. Walaupun demikian, secara keseluruhan skor yang diperoleh siswa kelas V SD Mutiara Singaraja dalam menulis karangan pribadi dengan teknik bercerita melalui menyimak cerita berbasis budaya Bali menunjukkan hasil yang baik sekali, yaitu sebesar 93,7.

Penilaian terhadap karangan pribadi didasari atas beberapa kriteria yang dijadikan pedoman. Kriteria tersebut ialah isi gagasan yang dikemukakan, organisasi isi, tata bahasa, gaya (pilihan struktur dan kosakata), dan ejaan/tata tulis (Nurgiyantoro, 2010: 440). Dalam hal ini, baik buruknya karangan pribadi bergantung pada kemampuan siswa mengungkapkan isi gagasan, organisasi isi, tata bahasa, pemilihan struktur kata, dan pemilihan ejaan yang sesuai dengan kaidah bahasa Indonesia. Isi gagasan yang dikemukakan dalam karangan pribadi tentu harus sesuai dengan topik yang dipilih dalam karangan. Selain kesesuaian, isi gagasan yang diungkapkan juga harus lugas dan menarik agar pembaca semakin tertarik untuk membacanya. Selain itu, organisasi isi dalam karangan pribadi harus diperhatikan. Hal ini tak lepas dari penyusunan ide yang tertata dengan baik, padat, dan menunjukkan kekohesifan antarkalimat. Kekohesifan antarkalimat selalu didukung oleh pemilihan kata yang tepat atau pemanfaatan potensi kata dalam kalimat. Pada bagian ini, proses pembentukan kata harus dikuasai dengan baik agar kata yang digunakan tidak menimbulkan pengertian yang berbeda.

Demikian halnya dengan struktur kata dalam kalimat, penggunaan bentuk bahasa harus berdasarkan konstruksi minimal sebuah kalimat. Kalimat yang dibangun dengan struktur kebahasaan akan menjadikan kalimat lebih komunikatif dan makna yang ingin disampaikan dalam kalimat tidak kabur. Kalimat yang komunikatif tentu selalu berlandaskan pada ejaan bahasa Indonesia. Oleh karena itu, penguasaan mengenai aturan penulisan tata kalimat harus dikuasai dengan sempurna agar kalimat yang dibentuk dapat mewakili gagasan/pikiran yang disampaikan. Jadi, untuk menghasilkan karangan pribadi yang baik, semua unsur yang menjadi penentu tersebut harus terpenuhi.

\section{Simpulan dan Saran}

Guru telah memberdayakan teknik bercerita sesuai dengan rencana pelaksanaan pembelajaran. Penerapan teknik pembelajaran tersebut sudah diintegrasikan dalam tahapan pembelajaran, baik pada tahap awal, inti, maupun penutup. Hasil belajar siswa kelas V SD Mutiara Singaraja dengan memberdayakan teknik bercerita berbasis budaya Bali dalam pembelajaran keterampilan menulis karangan pribadi berada dalam kategori baik sekali, yaitu sebesar 93,7. Sesuai dengan pedoman konversi skala sebelas, rentangan skor 85-94 dinyatakan dalam kategori baik sekali. Jadi, hasil belajar siswa kelas V SD Mutiara Singaraja dalam menulis karangan pribadi dengan teknik bercerita berbasis budaya Bali berada dalam kategori baik sekali, yaitu sebesar 93,7.

Berdasarkan hasil penelitian, para guru Bahasa dan Sastra Indonesia yang mengajar di SD Mutiara Singaraja disarankan agar menggunakan teknik bercerita berbasis budaya Bali dalam pembelajaran menulis sehingga pembelajaran lebih efektif dan dapat mencapai tujuan pembelajaran. Di samping itu, guru juga harus meningkatkan upaya dan cara mengajar, baik dalam penggunaan teknik pembelajaran maupun strategi-strategi yang digunakan dalam proses belajar-mengajar. 
Bagi siswa SD Mutiara Singaraja, khususnya kelas V, diharapkan lebih ditingkatkan lagi kemampuan dan kreativitas di dalam proses pembelajaran agar hasil yang diperoleh lebih maksimal. Di samping itu, siswa SD Mutiara Singaraja juga dapat mencari sumber-sumber lain yang menunjang proses pembelajaran.

\section{Daftar Rujukan}

Bachri, S Bachtiar. 2005. Pengembangan Kegiatan Bercerita, Teknik dan Prosedurnya. Jakarta: Depdikbud.

Bimo. 2011. "Pendidikan Karakter, Mau Kemana?" Diunduh pada http://kakbimo.wordpress.com/ 2011/07/28/pendidikan-karakter-mau-kemana/.

Jayanti, Ni Kadek Eka. 2016. Penerapan Metode Bercerita Berbasis Kearifan Lokal untuk Meningkatkan Moral Anak Kelompok B PAUD Widya Laksmi. E-Journal Pendidikan Anak Usia Dini Universitas Pendidikan Ganesha Volume 4. No. 2-Tahun 2016

Keraf, Gorys. 2001. Komposisi. Semarang: Nusa Indah.

Khotimah, Husnul. dkk. 2016. Upaya Peningkatan Keterampilan Menulis Karangan melalui Model Cooperative Script dengan Media Flashcard Berbasis Kearifan Lokal Pada Siswa Kelas IV SDN 2 Panjer Tahun Ajaran 2015/2016. Jurnal KALAM CENDEKIA, Volume 4, Nomor 6.1, hlm. 637-642

Nurgiyantoro, Burhan. 2010. Penilaian Pembelajaran Bahasa, Berbasis Kompetensi. Yogyakarta: BPFEYOGYAKARTA.

Tarigan, Henry Guntur. 2008. Menulis sebagai Suatu Keterampilan Berbahasa. Bandung: Angkasa.

Trianto. 2009. Model-model Pembelajaran Inovatif Berorientasi Konstruktivistik. Jakarta: Prestasi Pustaka Publisher.

Mulyati, Yeti. 2009. "Pembelajaran Bahasa Indonesia yang Berorientasikan Kompetensi Bahasa dan Kompetensi Berbahasa”. . Bandung: FPBS UPI.

Mundziroh, Siti. 2013. Peningkatan Kemampuan Menulis Cerita dengan Menggunakan Metode Picture and Picture pada Siswa Sekolah Dasar. BASASTRA Jurnal Penelitian Bahasa, Sastra Indonesia dan Pengajarannya, Volume 2 Nomor 1, April 2013.

Rumbiak, Aser. 2016. Peningkatan Keterampilan Menulis Cerita Menggunakan Media Gambar di SD Negeri Bakalan Bantul. Jurnal Pendidikan Guru Sekolah Dasar Edisi 5 Tahun ke-5 2016, hal 378-385.

Subiantoro. 2012. Membangun Karakter Bangsa Melalui Cerita Rakyat Nusantara (Model Pendidikan Karakter Untuk Anak Mi Awal Berbasis Cerita Rakyat Dalam Perspektif Sosiologi Pendidikan Islam), Jurnal Pendidikan Agama Islam, Vo.IX, No. 1 Juni 2012, hal 100.

Wati, Ni Made Sintia dkk. 2016. Penerapan Metode Bercerita Berbasis Kearifan Lokal untuk Meningkatkan Empati Anak Kelompok B1. e-Journal Pendidikan Anak Usia Dini Universitas Pendidikan Ganesha Volume 4. No. 2-Tahun 2016 